\title{
Correlational Analysis of Self-Regulation and Self-Efficacy with the Individuation Process among Adults
}

\author{
Nayanika Singh $^{1 *}$
}

\section{ABSTRACT}

The individuation process demarcates the core concept of Jungian Psychology that represents various systems and structures of personality. Jung defined individuation as the process by which a person becomes "a psychological in-dividual, that is separate, indivisible unity or whole that begins after the 35th year and is necessary for survival. Self-Regulation is one's ability to monitor, regulate and control one's behavior. According to Jung, individuation lies at the heart of one's individuation process. Self-Efficacy is defined as the ability of an individual to realize his/her potential to the fullest irrespective of adversities and obstacles. According to Jung, the primary goal of humans is to move toward the fulfillment or realization of their capabilities (Self-Efficacy) and achieving individuation. Against this backdrop, the present investigation was designed to study the relationship between self-regulation and self-efficacy with the individuation process among adults. Sample for the study consisted of 240 adults, age ranging 40-50 years, having a stable career and married life. Data was collected using questionnaires pertaining to the variables from Chandigarh, Mohali, Panchkula and Ludhiana. Since, it is the first of its kind attempt in the Indian context to provide elusive character to the construct of individuation, the index for individuation consisted of a cumulative score of self-concept, ego strength and inner directedness. The study consisted of two hypotheses: 1) Self-Regulation will have a positive significant relationship with the individuation process. 2) Self-Efficacy will have a positive significant relationship with the individuation process. Statistical analysis was done using Pearson's product moment correlation to study the relationship between self-regulation and self-efficacy and the individuation process. Results indicated that both self-regulation and selfefficacy were found to have positive significant relationship with the individuation process, thereby, both the hypotheses stand proved. However, more studies need to be conducted to validate the construct of Individuation process in the Indian context.

Keywords: Self-Regulation, Self-Efficacy, Individuation process, Adults.

\footnotetext{
${ }^{1}$ Research Scholar, Department of Psychology, Punjabi University, Patiala, India *Responding Author

(C) 2016 I N Singh; licensee IJIP. This is an Open Access Research distributed under the terms of the Creative Commons Attribution License (http://creativecommons.org/licenses/by/2.0), which permits unrestricted use, distribution, and reproduction in any Medium, provided the original work is properly cited.
} 
The individuation process demarcates the core concept of Jungian Psychology that represents various systems and structures of personality which get initially differentiated and then reintegrated during the course of the life-span. Jung (1960) strongly believed that the uniqueness of personality holds only for one's individual nature, but the process of personality development i.e. individuation-is inborn in every individual.

Jung defined individuation as the process by which a person becomes "a psychological individual, that is separate, indivisible unity or whole”. (Jung,1959) and for this psychological individual it is a matter of survival to be distinct and unique.

According to Jung, Individuation is a complicated process of intra-psychic differentiation and transformation that occurs throughout the second half of life (Wolitzby, 2006).

The individuation process consists of a few core ingredients that are as follows:

1) Unconscious- The unconscious is a realm of personality that is unknown to the conscious mind and is a rich storehouse of wisdom (Jung, 1953). The unconscious consists of:

- Personal Unconscious- In the words of Jung (1971), "personal unconscious consists of all of the acquisitions of personal existence including what has been forgotten, repressed, perceived, thought and felt."

- Collective Unconscious- is the storehouse of latent memory traces inherited from one's ancestral past, a past that includes the racial history of humans as separate species and their pre-human or animal ancestry (Hall, Lindzey and Campbell, 1998).

2) Consciousness- According to Jung, consciousness refers to all things we are personally aware of (i.e. thoughts, behaviors, and emotions) (Campbell, 1976).

3) Ego-The ego is the center and gatekeeper of the field of consciousness (Jung, 1971) that connects plays a vital role in connecting to our inner world.

4) Self- The Self is the midpoint of personality, around which all of the other systems are constellated and provides the personality with unity, equilibrium, and stability (Hall, Lindzey\& Campbell, 1998).

5) Archetypes- The task of individuation is to become aware of the archetypes (cognitive frameworks that are transmitted from one generation to the other) and their energy and to recognize their functioning in our daily lives (Hall, Lindzey and Campbell, 1998). According to Jung archetypes are of four types:

- Anima-According to Jung, the feminine archetype in man is called anima (Hall, Lindzey\& Campbell, 1998).

- $\quad$ Animus-the masculine archetype in woman called animus (Hall, Lindzey\& Campbell, 1998).

- $\quad$ Persona- According to Jung, the persona is a mask adopted by the person in response tradition and to his or her own inner archetypal needs (Hall, Lindzey\& Campbell, 1998). 
- $\quad$ Shadow-the shadow archetype consists of the animal instincts that humans inherited in their evolution from lower forms of life (Hall, Lindzey\& Campbell, 1998).

\section{THE PROCESS OF INDIVIDUATION:}

According to Jung this individuation process is never a question of "this or that" but always of “this and that" (Jung, 1954). The process of individuation is divided into two major stages which are as follows:

1) Morning Stage (Youth)- The Morning phase is the period of youth that extends roughly from the years just after puberty to middle age (up to $35^{\text {th }}$ year). It is a stage where the ego building process runs parallel within the differentiation (separation of parts from the whole that takes place spontaneously) of attitude and function types (Kincel, 1975).

2) Afternoon Phase (Adulthood)- The afternoon phase of the individuation begins between the thirty fifth and fortieth year and demarcates the stage of adulthood/Mid-life and plays the most important role in ones process of individuation.). According to Jung, however, the process of individuation begins after the age of 35 years. This stage is marked by differentiation of the unconscious contents from the consciousness and the formation of an inner relationship between the ego and the Self (Kincel, 1975).

Since, there is no standardized scale to measure the process of individuation, and it is the first of its kind attempt in the Indian context, based of Jungian literature and available research studies self-concept, ego strength and inner directedness have a significant role to play in ones process of individuation. Keeping this in mind the index for individuation would comprise of a cumulative score of self-concept, ego strength and inner directedness. The endeavor of the present research paper is to study the relationship between self-regulation and self-efficacy with the individuation process among adults. For which the variables are explained hereunder:

Self- Concept- According to Jung, the Self is the container and organizer of all opposites which is both a crucial ingredient within the process of uniting the opposites and the very end-product of this process, the union of opposites (individuation) itself (Huskinson, 2004).

Ego Strength-Barron (1953) asserts that the various aspects of effective personal functioning is usually subsumed under the term "ego strength. Jung (1916) believed that ego was the center of personality (deals with the conscious material alone) and was responsible for one's sense of identity.

Inner directedness-Inner-directedness is an inner drive to make conscious choices in accordance with those principles which are the highest in one-self (Dadrowski \& Piechowski, 1970).According to Jung, 'Only a man who can consciously assent to the power of their inner voice and inner resources become an integrated personality’ (individuated) (Samuels, 2004).

Self-Regulation- According to Pintrich (2000) Self- regulation/ self-regulated learning is as an active, applicable process that learners' set goals for their learning and their attempt to monitor, regulate, and control their cognition, motivation, and behavior; guided by contextual features in the environment. According to Jung, self- regulation lies at the heart of the individuation process

(C) The International Journal of Indian Psychology, ISSN 2348-5396 (e)| ISSN: 2349-3429 (p) | 68 
and, of the process of change in analysis, as it can help to bring about a new synthesis between the conscious and the unconscious (Knox, 2004).

Self-Efficacy-Self-efficacy refers to beliefs in one's capabilities to organize and execute the courses of action required to produce given attainments (Bandura, 1977). Jung's theory further acknowledges the assumption that humans tend to move toward the fulfillment or realization of their capabilities (Self-Efficacy) and achieving individuation-a fully harmonious and integrated personality is a primary goal (Corey \& Corey, 2010).

\section{Objectives:}

1. To study the relationship between Self-Regulation and the individuation process.

2. To study the relationship between Self-Efficacy and the individuation process.

\section{Hypotheses:}

1. Self-Regulation would have a positive significant relationship with the individuation process.

2. Self-Efficacy would have a positive significant relationship with the individuation process.

\section{METHOD:}

\section{Sample}

The sample for the present study comprised of 240 adults, age ranging from 40- 50 years. Data was collected from Chandigarh, Mohali, Panchkula and Ludhiana. Incidental sampling was used for assimilating the data pool. Matching within the sample was done on the indices of:

1. Education (Graduation and above).

2. Professional Stability- Self report of secure career functioning.

3. Marital Status- Married for at least 12 years.

\section{Tools Used:}

1) Self- Regulation Questionnaire (SRQ; Brown, Miller \& Lawendowski, 1999)- This is a self- report inventory designed to assess one's self- regulatory processes and functioning. The Self- Regulation Questionnaire consists of 63 items to be answered on a Likert scale ranging from1 (Strongly Disagree) to 9 (Strongly Agree). Scoring is done according to the instructions given in the manual.

2) General Self Efficacy Scale (GSE; Schwarzer \& Jerusalem, 1995)- This is a self - report inventory used to assess a person's general sense of perceived self- efficacy. The test also aims to predict a person's ability to cope with daily hassles after experiencing any kind of stressful life event/events. The General Self-Efficacy scale consists of ten statements to which the respondents are to respond on a 4 point scale depicting one's level of self-efficacy. Scoring is done by adding up scores on all the ten items. 
3) Personal Orientation Inventory (POI; Shostrom, 1963)- This inventory consists of 150 comparative value judgment items used to measure attitudes, values, and behaviors based on Maslow's model of self - actualization. POI consists of two major scales of Inner-directedness \& Time Competence scale and Ten sub-scales. For the present study only the scale of inner directedness consisting of 127 items was used. Scoring consisted of instructions given in the manual.

4) C-Factor of 16- PF (Cattell \& Eber, 1962)- The 16 PF inventory was constructed by Cattell to cover the whole range of adult personality in terms of the most fundamental dimensions which comprehensively span the entire range of personality characteristics in adults. Factor- C (i.e. emotional stability vs. high ego strength) comprised of 26 items (13 each from Form (A) and Form (B) of the 16 PF). The items have been combined to make standardized working instrument for measuring ego strength. Scoring is done according to instruction mentioned in the scoring key.

5) Six- Factor Self-Concept Scale (SFSCS; Stakes, 1994)- The SFSCS is a 36-item multidimensional scale designed to evaluate the self-concept and cognitive self-perceptions of adults using descriptive adjectives/phrases across six domains/constructs (i.e. Task accomplishment, morality, vulnerability, power, giftedness \& likeability). Each phrase is rated on a scale ranging from 1 (Never or almost never true of you) to 7(Always or almost always true of you). Scoring is done according to instructions mentioned in the manual.

6) Index for Individuation: For the objective assessment of the individuation process the present investigation would use the cumulative score of Self-Concept, Ego Strength and Innerdirectedness as a relative index to measure the individuation process among adults.

\section{Statistical Analysis:}

Pearson's product moment correlation will be used to study the relationship of self- regulation and self-efficacy with the Individuation Process among Adults.

\section{RESULTS\& DISCUSSION:}

Correlation Coefficients indicating relationship of Self - Regulation (S.R) and SelfEfficacy(S.E) with the Individuation Process (Index of Individuation consisting of Selfconcept, Ego Strength and Inner directedness)

\begin{tabular}{|l|l|l|l|l|l|l|}
\hline & S.C & E.S & I.D & INDEX & S.R & S.E \\
\hline SELF-CONCEPT(S.C) & 1.00 & & & & & \\
\hline EGO STRENGTH (E.S) & $\mathbf{0 . 3 1} * *$ & 1.00 & & & & \\
\hline INNER- DIRECTEDNESS (I.D) & 0.07 & $\mathbf{0 . 2 3} * *$ & 1.00 & & & \\
\hline INDEX & $\mathbf{0 . 8 4} *$ & $\mathbf{0 . 5 2 * *}$ & $\mathbf{0 . 5 2} * *$ & 1.00 & & \\
\hline S.R & $\mathbf{0 . 2 1} \mathbf{2}^{* *}$ & $\mathbf{0 . 1 7 ^ { * * }}$ & 0.11 & $\mathbf{0 . 2 4} * *$ & 1.00 & \\
\hline S.E & $\mathbf{0 . 3 3 ^ { * * }}$ & $\mathbf{0 . 2 7 * *}$ & $\mathbf{0 . 2 2} * *$ & $\mathbf{0 . 4 0 * *}$ & $\mathbf{0 . 4 4} * *$ & 1.00 \\
\hline
\end{tabular}

${ }^{*} \mathrm{p}<0.05, * * \mathrm{p}<0.01$ 


\section{Correlational Analysis of Self-Regulation and Self-Efficacy with the Individuation Process among Adults}

Table 1 depicts the correlation coefficients indicating the relationship among the sub-dimensions of individuation as the Index of individuation (dependent variable) and self- efficacy and selfregulation as independent predictor variables.

For the present study the index for the individuation process was measured with the cumulative effect of self-concept, ego-strength and Innerdirectedness. The correlation analyses reveals positive significant relationship of self-concept $(r=.84, \mathrm{p}<.01)$, ego-strength $(\mathrm{r}=.52, \mathrm{p}<.01)$ and Innerdirectedness $(\mathrm{r}=.52, \mathrm{p}<.01)$ with the individuation process at 0.05 and 0.01 levels.

Therefore from above correlation coefficients one can conclude that self- concept has a stronger potential relationship with the individuation process than ego-strength and Innerdirectedness. However, ego strength and innerdirectedness have also played a significant role in contributing to ones process of individuation.

Table 1 further depicts the correlation coefficients indicating the relationship among the subdimensions of individuation as the Index of individuation (dependent variable) and self- efficacy and self-regulation as independent predictor variables in the present study. According to Hypothesis oneself-regulation would have a positive significant relationship with the individuation process. The bivariate correlation shows significant positive correlation between individuation and self-regulation $(r=.24, \mathrm{p}<.01)$. Hence, the respective hypothesis is accepted. The plausible explanation for self-regulation to have a positive significant relationship with the process of individuation could be attributed to the fact that according to Jung, self- regulation (which is one's ability to monitor, regulate and control his/her own behavior) lies at the heart of the individuation process and, of the process of change in analysis, it can help to bring about a new synthesis between the conscious and the unconscious (Knox, 2004) leading to an integrated whole personality.

Hypothesis two of the present study states that self-efficacy would have a positive significant relationship with the individuation process. The bivariate correlations shows self-efficacy $(\mathrm{r}=$ $.40, \mathrm{p}<.01$ ) has a significant positive relationship with the individuation process. It also indicates that hypothesis two of the current study is also accepted due to strong mutual relationship of self-efficacy and ones process of individuation. The major reason for self-efficacy to have a positive significant relationship with the individuation process could be that since selfefficacy deals with an individual's capacity to realize his/her potential to the fullest and to persevere even in times of adversity, obstacles and failureand ones drive toward individuation is inherent in the organism that presses for the actualization of the ground plan written in the psyche where this drive seeks to make the individual conscious of his/her potentialities (selfefficacy) and helps in making better choices (Johnson, 1988), aiding in contributing towards wholeness paving way toward individuation.

The correlation values also indicate positive significant relationship of the index related variables and the predictor variables with each other. The results are as follows: 
1. Ego strength was found to have a positive significant relationship with self-concept $(\mathrm{r}=.31, \mathrm{p}<.01)$.

2. Innerdirectedness was found to have a positive significant relationship with ego strength $(\mathrm{r}=.23, \mathrm{p}<.01)$.

3. Self-Regulation was found to have a positive significant relationship with self-concept $(r=.21, \mathrm{p}<.01)$ and ego strength $(r=.17, \mathrm{p}<.01)$.

4. Self-Efficacy was found to have a positive significant relationship with self-concept $(\mathrm{r}=.33, \mathrm{p}<.01)$, ego strength $(\mathrm{r}=.27, \mathrm{p}<.01)$ and innerdirectedness $(\mathrm{r}=.22, \mathrm{p}<.01)$.

5. Innerdirectedness was found to have a positive non-significant relationship with selfconcept ( $r=.07, \mathrm{p}>.01)$.

6. Self-Regulation was found to have a positive non-significant relationship with innerdirectedness $(\mathrm{r}=.11, \mathrm{p}>.01)$

\section{CONCLUSION}

Though this research is a novel approach in operationalizing and providing elusive character to process of individuation, however, since this is the first of its kind study in the Indian context, more such research needs to be undertaken on diverse adult population to substantiate and validate the same.

\section{REFERENCES}

Andrews, G., Singh, M., \& Bond, M. (1993).The Defense Style Questionnaire. Journal of Nervous and Mental Disease, 181,246- 256.

Bandura, A. (1977). Social Learning Theory. New Jersey : Prentice- Hall, Englewood Cliffs.

Barron, F. (1953).An ego-strength scale which predicts response to psychotherapy. Journal of Consulting Psychology, 17(5), 327-333.

Campbell, J. (1976).The Portable Jung. Toronto: Penguin Books Ltd.

Cattell, R.B., \&Eber, H.W. (1962).The Sixteen personality factor questionnaire. Champaign, Illinois: IPAT.

Corey, G., \& Corey, S.M. (2010).I Never Knew I Had a Choice: Explorations in Personal Growth ( $9^{\text {th }}$ Ed.). Canada: Cengage Learning.

Dabrowski, K., Kawezak, A., \& Piechowski, M.M. (1970).Mental growth through positive disintegration. London: Gryf.

Hall, C.S., Lindzey, G., \& Campbell, J.B. (1998).Theories of Personality (4 ${ }^{\text {th }}$ Ed.).John Wiley \& Sons, Inc.

Huskinson, L. (2004). Nietzche and Jung: The Whole Self in the Union of Opposites. Hove \& New York : Brunner- Routledge.

Johnson, B.C. (1988). Pastoral Spirituality: A Focus For Ministry. Pennsylvania: Westminster Press.

Jung, C.G. (1916). Septom Sermons ad mortuos, In Memories, Dreams and Reflections. New York: Vintage Books, 1989. 
Jung, C. G. (1953). Two Essays on Analytical Psychology. In H. Read, M. Fordham \& G. Adler (Eds.). New York: Pantheon Books.

Jung, C.G. (1954).Symbols of Transformation, Collected Works Vol. 5. Princeton: Princeton University Press.

Jung, C.G. (1959). Collected Works of C.G. Jung, Vol.9 Part I, In H. Read, M. Fordham and G. Adler Eds. New York : Bollingen Foundation, Inc., and Pantheon Books.

Jung, C.G. (1960). The Structure and Dynamics of the Psyche, In H. Read, M. Fordham, G. Adler Eds.And Trans. New York : Pantheon Books.

Jung, C.G. (1971). Psychological Types, In H. Read, M. Fordham, G. Adler EdSs. And Trans. New York: Pantheon Books.

Kincel, R.L. (1975). C.G. Jung's Individuation Process. Thesis, University of Ottawa, Canada.

Knox, J. (2004). Developmental aspects of analytical psychology: new perspectives cognitive neuroscience and attachment theory. In Joseph, Cambray \& Linda, Carter (Edition), Analytical Psychology Contemporary Perspectives in Jungian Analysis. USA: BrunnerRoutledge

Pintrich, P. (2000). The Role of Goal Orientation in Self Regulated Learning. In J. Boekarts, P. Pintrich\& M. Zeidner (Eds.), Handbook of Self-Regulation. Burlington, MA: Elsevier Academic Press.

Schwarzer, R., \& Jerusalem, M. (1995). General Self-Efficacy Scale. In J. Weinman, S. Wright, \& M. Johnston (Eds.) Measures in health psychology: A user's portfolio. Causal and control beliefs. Windson, U.K :Nfer-Nelson.

Shostrom, E.L. (1963). Personal Orientation Inventory. Manual, Educational and Industrial Testing Service. San Diego.

Stake, J.E. (1994).Developments and Validation of the Six- Factor Self Concept Scale for Adults. Educational and Psychological Measurement, 54, 56-71.

Wolitzby, D.L. (2006). Psychodynamic Theories, In Jay C. Thomas and Daniel, L. Segal (Eds.), Comprehensive Handbook of Personality and Psychopathology. New Jersey: John Wiley \& Sons.

How to cite this article: N Singh (2016), Correlational Analysis of Self-Regulation and SelfEfficacy with the Individuation Process among Adults, International Journal of Indian Psychology, Volume 3, Issue 3, No. 10, DIP: 18.01.179/20160303, ISBN: 978-1-365-19879-3 